\title{
ANALISIS KESULITAN SISWA DALAM MENYELESAIKAN SOAL KEMAMPUAN BERPIKIR LOGIS MATEMATIS
}

\author{
Anisa Kurnia Septiya Utami ${ }^{1 \bowtie}$ dan Haerudin ${ }^{2}$ \\ 1,2Program Studi Pendidikan Matematika, Universitas Singaperbangsa Karawang
}

\section{Info Artikel Abstract}

Sejarah Artikel:

Diterima 18 Jan 2021

Direvisi 26 Mar 2021

Disetujui 19 Apr 2021

Keywords: Analysis of Students' Difficulty,

Thinking Ability,

Logical-Mathematical

Thinking Ability.

Paper type:

Research paper
This study aims to determine how the students' difficulties in solving the test questions with indicators of the logical-mathematical thinking ability in one of the geometry materials, especially cubes. This study was conducted according to the facts in 9th-grade of SMP Negeri (State Junior High School)in one of the schools in Karawang Regency. This study used descriptive research with a qualitative approach. The data were collected by an essay test consisting of 4 questions, and interviews. The subjects of the study were 28 9th-grade students of SMPN 1 Cikampek Karawang Regency. The instrument of the study used the essay test with indicators of logical-mathematical thinking ability according to (Andini, 2017): (1) The ability to conclude based on the appropriate portion; (2) The ability to conclude based on the examples; 3) The ability to conclude based on the existing data; (4) The ability to conclude based on the relationship between two variables. The data analysis techniques used were data collection, data reduction, data presenting, and concluding. The results of the study in the geometry materials show that all indicators of logical-mathematical thinking ability have not been achieved maximally. Only students with high category who meet the indicator, while the students who have moderate and low categories cannot meet the indicators. Out of 28 students, 3 students are in the high category with a percentage of $10.71 \%, 75 \%$ of students are in the moderate category, and 4 students are in the low category with a percentage of $14.29 \%$. These results of the study show that students still have difficulty understanding and mastering the concepts to solve the test questions with the indicators of logical-mathematical thinking ability.

\begin{abstract}
Abstrak
Penelitian ini bertujuan untuk mengetahui bagaimana kesulitan siswa dalam menyelesaikan soal tes dengan indikator kemampuan berpikir logis matematis pada salah satu materi bangun ruang sisi datar khususnya kubus. Penelitian ini dilakukan berdasarkan fakta yang telah terjadi pada kelas IX SMP Negeri pada salah satu sekolah di kabupaten Karawang. Penelitian ini menggunakan jenis penelitian deskriptif dengan pendekatan kualitatif. Pengumpulan data diperoleh dengan cara tes uraian sebanyak 4 soal sesuai indikator kemampuan berpikir logis matematis dan wawancara. Subjek penelitian ini adalah siswa kelas IX SMPN 1 Cikampek Kabupaten Karawang berjumlah 28 siswa. Penelitian ini menggunakan instrument tes dengan indikator kemampuan berpikir logis matematis menurut (Andini, 2017): 1) Kemampuan menarik kesimpulan berdasarkan proporsi yang sesuai; 2) Kemampuan menarik kesimpulan berdasarkan contoh - contoh; 3) Kemampuan menarik kesimpulan berdasarkan data yang ada; 4) Kemampuan menarik kesimpulan berdasarkan hubungan antar dua variabel. Teknik analisis data yang digunakan yaitu pengumpulan data, reduksi data, penyajian data dan penarikan kesimpulan. Hasil penelitian pada materi bangun ruang menunjukkan bahwa seluruh indikator kemampuan berpikir logis belum terpenuhi secara maksimal, hanya siswa dengan kemampuan kategori tinggi yang memenuhi indikator, sedangkan siswa yang kemampuannya berkategori sedang dan rendah tidak mampu memenuhi indikator. Dari 28 siswa, terdapat siswa yang berkategori tinggi dengan persentase $10,71 \%$ ada 3 siswa, siswa yang berkategori sedang memperoleh persentase $75 \%$ sedangkan siswa yang berkategori rendah sebanyak 4 siswa dengan persentase 14,29\%. Dengan adanya hasil dalam penelitian ini menunjukkan bahwa siswa masih mengalami kesulitan dalam memahami dan menguasai konsep untuk menyelesaikan soal tes dengan indikator kemampuan berpikir logis matematis.
\end{abstract}

(C) 2021 Universitas Muria Kudus
p-ISSN 2615-4196 e-ISSN 2615-4072

Alamat korespondensi:

Program Studi Pendidikan Matematika

Fakultas Keguruan dan Ilmu Pendidikan Universitas Muria Kudus

Kampus UMK Gondangmanis, Bae Kudus Gd. L. 1t I PO. BOX 53 Kudus

Tlp (0291) 438229 ex.147 Fax. (0291) 437198

E-mail: akurseptiya13@gmail.com 
Anisa Kurnia Septiya Utami dan Haerudin

Anargya: Jurnal Pendidikan Matematika, Vol. 4 No.1, April 2021

https://dx.doi.org/10.24176/anargya.v4i1.5762

\section{PENDAHULUAN}

Matematika ialah salah satu ilmu pengetahuan yang memiliki karakteristik objek bersifat abstrak, sehingga dalam pembelajaran matematika siswa seringkali dihadapkan dengan suatu masalah yang rumit. Matematika juga sebagai salah satu pelajaran yang wajib diikuti oleh siswa dalam setiap tingkatan pada jenjang sekolah dasar maupun sekolah menengah, sehingga dapat membekali siswa dalam mengasah kemampuan berpikir. Oleh karena itu, dibutuhkan kemampuan berpikir yang tidak mudah. Berpikir merupakan suatu kegiatan untuk mengembangkan ide atau konsep yang ada dalam pemikiran seseorang sehingga menghasilkan suatu pemikiran.

Kemampuan berpikir dalam diri manusia terdapat diantaralain kemampuan berpikir kritis, analisis, kreatif, logis, sistematis serta kemampuan bekerjasama. Berpikir logis memuat kegiatan matematika dan kegiatan penalaran seperti: pemahaman koneksi, dan penyelesaian masalah komunikasi secara logis, Sumarmo (Andini, 2017). Kemampuan berpikir logis sangat diperlukan pada proses pemecahan masalah, sehingga siswa yang mampu melakukan proses pemecahan masalah memiliki kemampuan berpikir logis yang baik, Ni'matus (Noviani et al., 2020).

Berpikir siswa bisa diukur berdasarkan dengan indikator kemampuan berpikir, salah satunya dengan menggunakan indikator kemampuan berpikir logis. Menurut Sumarmo (Octaria, 2017) "Kemampuan berpikir logis meliputi kemampuan: (1) menarik kesimpulan atau membuat, penarikan dan interprestasi berdasarkan proporsi yang sesuai, (2) menarik kesimpulan atau membuat perkiraan dan prediksi berdasarkan peluang, (3) menarik kesimpulan atau membuat perkiraan atau prediksi berdasarkan korelasi antara dua variabel, (4) menetapkan kombinasi beberapa variabel, (5) analogi adalah menarik kesimpulan berdasarkan keserupaan dua proses, (6) melakukan pembuktian, (7) menyusun analisa dan sintesa beberapa kasus". (Andini, 2017) menyimpulkan bahwa indikator kemampuan berpikir logis adalah: 1. Kemampuan menarik kesimpulan berdasarkan proporsi yang sesuai, 2. Kemampuan menarik kesimpulan berdasarkan contoh - contoh, 3. Kemampuan menarik kesimpulan berdasarkan data yang ada, 4 . Kemampuan menarik kesimpulan berdasarkan hubungan antar dua variabel.

Kemampuan berpikir logis dalam matematika dapat mempengaruhi hasil belajar peserta didik dan sebagai salah satu faktor yang sangat penting bagi perkembangan kognitif peserta didik, (Pratiwi et al., 2019). Namun, pada kenyatannya masih ditemukan asumsi - asumsi bahwa matematika salah satu pelajaran sulit, bila dibandingkan dengan beberapa mata pelajaran lainnya sehingga siswa tidak mengasah kemampuan berpikir logis dalam menyelesaikan permasalahan dalam pelajaran matematika. Kemampuan siswa dalam berpikir logis masih rendah hal ini terlihat ketika siswa mengalami kesulitan untuk menarik kesimpulan berdasarkan data yang ada dari soal matematika, (Andini, 2017).

Fakta di lapangan menunjukkan bahwa berdasarkan hasil jawaban tes uraian yang peneliti berikan dan hasil wawancara kepada guru matematika Sekolah Menengah Pertama (SMP) Negeri pada salah satu wilayah yang ada di kabupaten Karawang mengatakan banyak siswa yang berkemampuan berpikir logisnya yang masih kurang dan mengalami kesulitan dalam menyelesaikan soal - soal. Hal tersebut terlihat pada hasil jawaban tes uraian peneliti, dan tugas serta ulangan yang diberikan oleh guru bahwa nilai yang sudah diperoleh siswa masih belum mencapai Kriteria Ketuntasan Minimal (KKM) serta masyoritas siswa yang menjawab tidak sesuai pertanyaan soal tes indikator kemampuan berpikir logis matematis. Hal ini diperkuat oleh pernyataan bahwa siswa masih kurang untuk menyelesaikan soal kemampuan berpikir logis, sehingga hasil ulangan harian nilai siswa masih dibawah KKM.

Kesulitan belajar adalah sebuah permasalahan yang dapat menyebabkan seorang siswa tidak dapat mengikuti proses pembelajaran dengan baik yang disebabkan oleh faktor yang menghambat sehingga tidak dapat mencapai tujuan sesuai dengan yang diharapkan, Irham \& Wiyani (Rumantinigsih et al., 2020).

Kesulitan siswa terjadi karena kurang teliti dalam membaca pertanyaan sehingga siswa kesulitan untuk memahami dan menjawab soal soal. Hal ini diperkuat oleh penelitian terdahulu yang mengatakan bahwa siswa kurang cermat dalam membaca serta memahami kalimat mengenai apa yang diketahui dan ditanyakan dalam soal, ini menjadi penyebab siswa kesulitan dalam mengerjakan soal dalam bentuk cerita, Muncarno (Sudirman et al., 2018).

Kesulitan belajar akan mengganggu aktivitas pembelajaran pada siswa karena tersebut siswa menjadi malas untuk berpikir dalam menyelesaikan soal, sehingga perlunya untuk 
mengetahui kesulitan - kesulitan yang dialami oleh siswa ketika menyelesaikan soal supaya dapat meminimalisir kesulitan yang dialami. Hal ini sesuai dengan penelitian (Alawiyah et al., 2016) bahwa apabila kesulitan belajar tidak segera diatasi maka proses penerimaan pengetahuan baru akan terus - menerus selalu mengganggu siswa.

Pentingnya kemampuan berpikir logis matematis yang terdapat pada tes uraian menyebabkan perlunya mengetahui tentang bagaimana kesulitan siswa dalam menyelesaikan soal tes dengan indikator kemampuan berpikir logis matematis. Dalam penelitian ini bermaksud untuk mengetahui sekaligus mendeskripsikan kesulitan yang dialami oleh siswa dalam menyelesaikan pertanyaan tes dengan indikator kemampuan berpikir logis matematis.

\section{METODE PENELITIAN}

Pendekatan kualitatif dianggap sesuai dengan tujuan dari penelitian yang akan dilakukan yaitu menghasilkan data deskriptif berupa kata dari subjek. Metode dalam penelitian ini menggunakan studi kasus, sehingga penelitian ini memfokuskan pada suatu fenomena yaitu kesulitan siswa menyelesaikan kemampuan berpikir logis matematis untuk dipahami dan dianalisis secara lebih mendalam. Teknik pengumpulan data diperoleh dengan cara tes uraian sebanyak 4 soal yang telah disesuaikan dengan indikator kemampuan berpikir logis matematis dan wawancara.

Subjek dalam penelitian ini ialah siswa kelas IX Sekolah Menengah Pertama (SMP) Negeri pada salah satu wilayah yang ada di kabupaten Karawang, dengan jumlah sebanyak 28 siswa. Penelitian ini menggunakan tahapan teknik analisis data dengan cara pengumpulan data, reduksi data, penyajian data dan kesimpulan

Penelitian ini menggunakan instrument tes dengan indikator kemampuan berpikir logis matematis menurut (Andini, 2017): 1) Kemampuan menarik kesimpulan berdasarkan proporsi yang sesuai; 2) Kemampuan menarik kesimpulan berdasarkan contoh - contoh; 3) Kemampuan menarik kesimpulan berdasarkan data yang ada; 4) Kemampuan menarik kesimpulan berdasarkan hubungan antar dua variabel.

\section{HASIL DAN PEMBAHASAN}

Berdasarkan hasil dan wawancara yang telah dilakukan, maka telah diperoleh hasil tes siswa dengan indikator kemampuan berpikir logis dari siswa pada kelas IX Sekolah Menengah
Pertama (SMP) Negeri pada salah satu wilayah yang ada di kabupaten Karawang, sebagaimana untuk mengetahui tingkat kesulitan siswa berdasarkan kategori. Oleh karena itu, peneliti mengelompokkan siswa tersebut berdasarkan nilai - nilai dengan kategori tinggi, sedang, dan rendah. Dengan menggunakan cara yang dijelaskan oleh (Arikunto, 2010) yaitu pada Tabel 1 berikut.

Tabel 1. Kriteria Pengelompokkan Siswa Pada Kemampuan Berpikir Logis

\begin{tabular}{cccc}
\hline $\begin{array}{c}\text { Kriteria } \\
\text { Pengelompokkan }\end{array}$ & Kategori & $\begin{array}{c}\text { Jumlah } \\
\text { Siswa }\end{array}$ & Persentase \\
\hline $\mathrm{N} \geq 64,53$ & Tinggi & 3 & $10,71 \%$ \\
\hline $43.05 \leq \mathrm{N}<64,53$ & Sedang & 21 & $75 \%$ \\
\hline $\mathrm{N}<43,05$ & Rendah & 4 & $14,29 \%$ \\
\hline Berdasarkan data & pada & tabel dapat
\end{tabular}

disimpulkan bahwa dari 28 siswa, terdapat siswa yang berkategori tinggi dengan persentase $10,71 \%$ ada 3 siswa, siswa yang berkategori sedang memperoleh persentase $75 \%$ sedangkan siswa yang berkategori rendah sebanyak 4 siswa dengan persentase $14,29 \%$. Pencapaian hasil siswa dalam menyelesaikan pertanyaan dengan indikator kemampuan berpikir logis ini masih rendah karena hasil jawaban siswa mayoritas mengalami kesulitan. Sehingga terjadi kesalahan dalam perhitungan, kesulitan dalam menentukan proporsi yang sesuai, tidak mengingat materi kubus dan salah dalam menentukan rumus. Kemampuan berpikir logis matematis siswa ketika menyelesaikan pertanyaan materi kubus dapat dikatakan masih mengalami kesulitan. Hal ini sejalan dengan (Utomo, 2019) yang mengatakan bahwa peserta didik yang memiliki tingkat kemampuan awal sedang dan terutama rendah akan mengalami kesulitan ketika memahami materi dan menyelesaikan masalah, sedangkan peserta didik dengan kemampuan awal tinggi pastinya tidak akan mengalami kesulitan dalam memahami materi matematika.

Pada pembahasan akan dibahas mengenai analisis kesulitan siswa dalam menyelesaikan materi kubus berdasarkan kemampuan kategorinya sebagai berikut:

Tabel 2. Kesulitan berdasarkan Kemampuan Kategori Tinggi

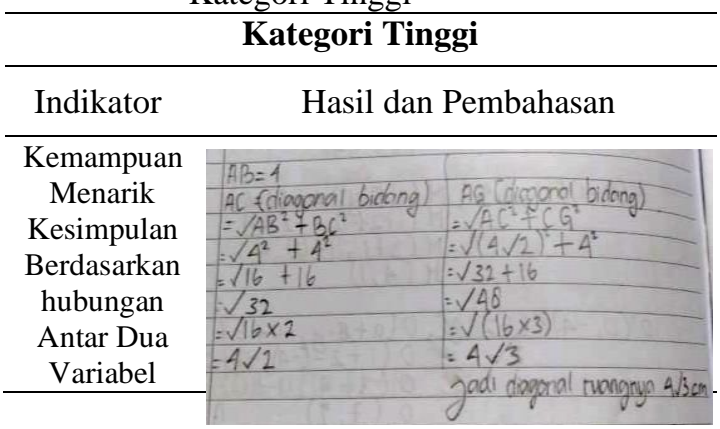


Anisa Kurnia Septiya Utami dan Haerudin

Anargya: Jurnal Pendidikan Matematika, Vol. 4 No.1, April 2021

https://dx.doi.org/10.24176/anargya.v4i1.5762

Jawaban siswa pada kelompok kategori tinggi, sudah dapat menarik hubungan dengan benar dalam menentukan panjang diagonal sisi dan diagonal ruangnya menggunakan rumus phytagoras sehingga tidak mengalami kesulitan.

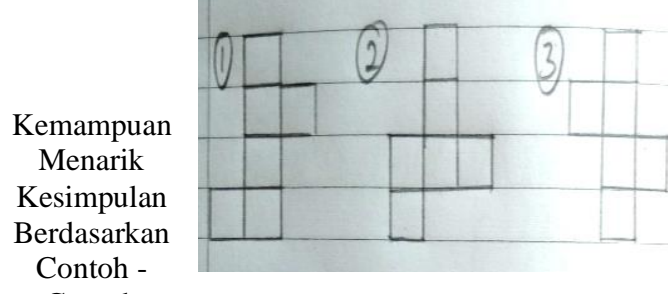

Jawaban siswa pada kelompok kategori tinggi, sudah dapat menarik kesimpulan berdasarkan contoh - contoh dengan benar dan tidak mengalami kesulitan.

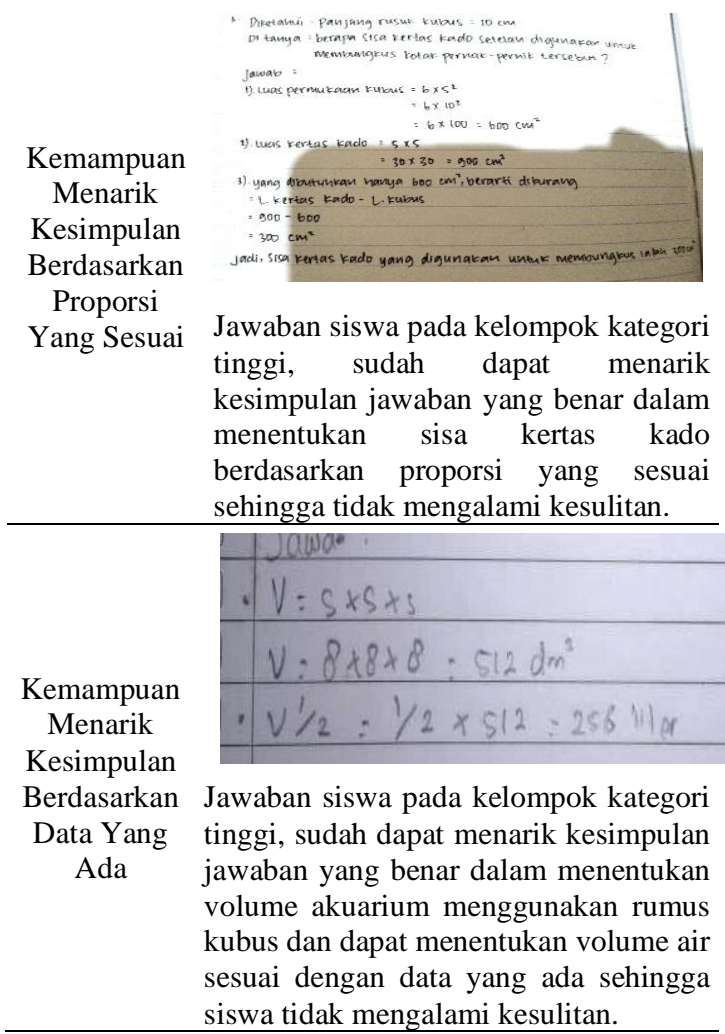

Berdasarkan hasil yang terdapat pada kategori tinggi, dapat disimpulkan bahwa siswa tidak mengalami kesulitan karena siswa dapat menyelesaikan soal yang diberikan dengan benar. Maka dapat dikatakan bahwa siswa dengan kategori kemampuan tinggi mampu untuk menyelesaikan semua indikator. Pada hasil wawancara, siswa mengatakan bahwa sudah memahami pertanyaan pada soal yang diberikan dan mudah untuk menjawab soal - soal, sehingga dalam hal ini siswa tidak mengalami kesulitan. Hal ini diperkuat oleh (Dwidarti et al., 2019) yang mengatakan bahwa subjek mampu untuk memahami maksud dari soal yang diberikan, sehingga subjek dapat menyelesaikan soal dengan mudah.

Tabel 3. Kesulitan berdasarkan kemampuan

\begin{tabular}{cc} 
& Kategori Sedang \\
\hline Kategori Sedang \\
\hline Indikator & \multicolumn{1}{c}{ Hasil dan Pembahasan } \\
\hline & Jawab \\
& $A G($ diagonal bidang $)$ \\
& $=A C^{2}+C G^{2}$ \\
& $=\sqrt{[} 4 \sqrt{2}]^{2}+4^{2}$ \\
& $=\sqrt{32}+16$ \\
& $=48$ \\
Memampuan & $=\sqrt{(16 \times 3)}$ \\
Kesimpulan & $=4 \sqrt{3}$ \\
Berdasarkan & \\
hubungan & $\begin{array}{l}\text { Jawaban siswa pada kelompok kategori } \\
\text { Antar Dua } \\
\text { Variabel } \\
\text { sedang, sudah dapat menarik hubungan } \\
\text { dalam menentukan panjang diagonal } \\
\text { ruang menggunakan rumus phytagoras, } \\
\text { tetapi dalam proses penyelesaiannya } \\
\text { masih mengalami kesulitan dalam } \\
\text { mengingat rumus dan tidak memahami } \\
\text { simbol }- \text { simbol dalam matematika } \\
\text { sehingga banyak siswa tidak melewati } \\
\text { tahapan menentukan panjang diagonal } \\
\text { sisinya dengan baik. }\end{array}$ \\
\hline &
\end{tabular}

\begin{tabular}{cl}
\hline Kemampuan \\
Menarik
\end{tabular}

Kemampuan

Menarik

Kesimpulan

Berdasarkan

Proporsi

Yang Sesuai

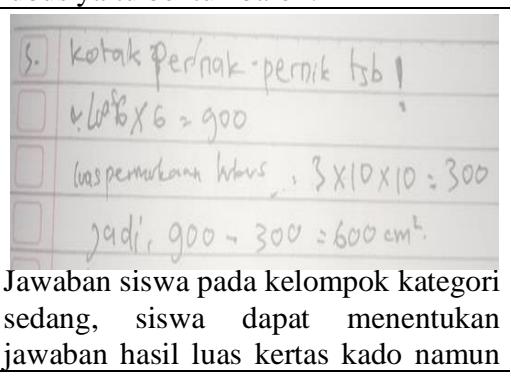




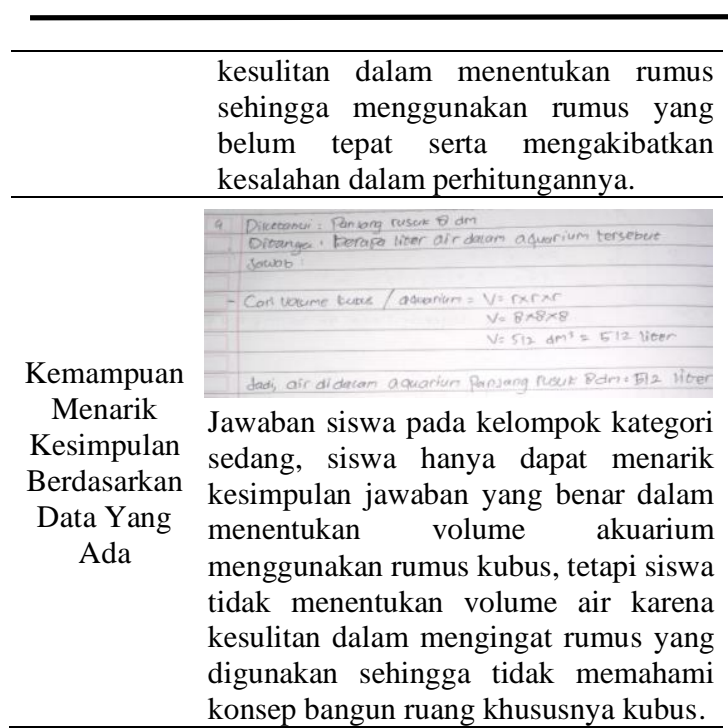

Berdasarkan hasil yang terdapat pada kategori sedang, dapat disimpulkan bahwa siswa mengalami kesulitan diakhir penyelesaian seperti tidak mengingat rumus, dan tidak mengingat bentuk bangun datar.

Hasil analisis yang diperoleh pada indikator kemampuan menarik kesimpulan berdasarkan hubungan antar dua variabel dan kemampuan menarik kesimpulan berdasarkan proporsi dapat disimpulkan bahwa masih diperoleh hasil tes yang dikatakan sedang. Hal ini dikarenakan siswa masih mengalami kesulitan ketika menentukan rumus sehingga siswa belum dapat menguasai indikator tersebut. Fakta tersebut sesuai dengan pernyataan (Andini, 2017) mengatakan bahwa dalam indikator kemampuan menarik kesimpulan berdasarkan proporsi yang sesuai masih rendah dikarenakan siswa tidak mengetahui konsep dalam pertanyaan sehingga tidak dapat menyelesaikan sesuai dengan pertanyaan dalam soal.

Hasil analisis yang diperoleh pada indikator kemampuan menarik kesimpulan berdasarkan contoh - contoh, siswa tidak memahami konsep bentuk bangun datar, serta kemampuan menarik kesimpulan berdasarkan data yang ada dapat disimpulkan bahwa masih diperoleh hasil tes yang dikatakan sedang. hal ini terlihat bahwa siswa belum dapat menarik kesimpulan dengan benar, karena jawaban siswa menggunakan volume kubus yang belum lengkap dalam proses perhitungannya. sehingga menunjukkan bahwa kemampuan menarik kesimpulan berdasarkan data yang ada belum dapat dicapai oleh siswa, karena mayoritas siswa mengalami kesulitan untuk menyimpulkan soal dalam bentuk cerita. Hal ini sependapat dengan

(Agustini \& Pujiastuti, 2020) yang mengatakan bahwa siswa masih kesulitan dalam mengubah soal bentuk cerita ke dalam kalimat matematika, sehingga siswa tidak dapat menyatakan konsep. Berdasarkan hasil wawancara siswa mengatakan bahwa sudah lupa dengan materi bangun datar dan hanya menjawab setengah cara saja yang penting terjawab.

Tabel 4. Kesulitan berdasarkan kemampuan Kategori Rendah

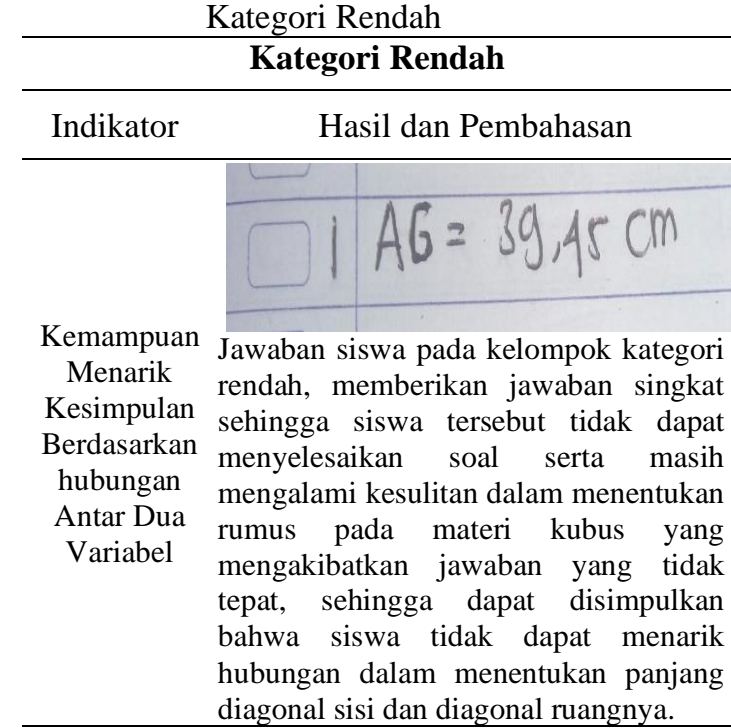

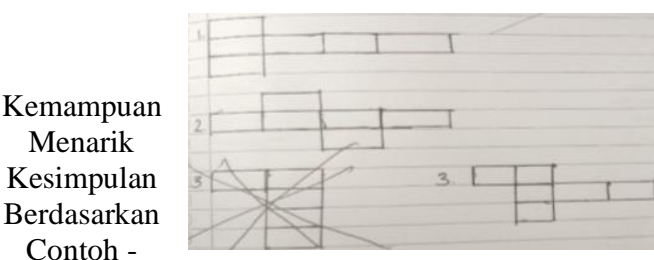

Jawaban siswa pada kelompok kategori rendah, mengalami kesulitan dalam mengingat bentuk kubus sehingga menggambarkan jaring - jaring balok.

Kemampuan

Menarik

Kesimpulan

Berdasarkan Jawaban siswa pada kelompok kategori

Proporsi rendah, siswa menuliskan jawaban yang

Yang Sesuai tidak sesuai dengan pertanyaan.

Kemampuan Menarik

Kesimpulan

Berdasarkan

Data Yang Ada

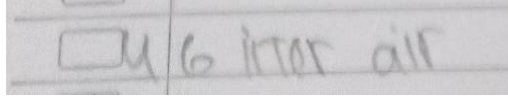

Jawaban siswa pada kelompok kategori rendah, siswa kesulitan untuk menyelesaikan pertanyaan dalam soal tes kemampuan berpikir logis sehingga jawabannya kurang tepat dan mengakibatkan kesalahan dalam menjawab. 
Anisa Kurnia Septiya Utami dan Haerudin

Anargya: Jurnal Pendidikan Matematika, Vol. 4 No.1, April 2021

https://dx.doi.org/10.24176/anargya.v4i1.5762

Berdasarkan hasil yang terdapat pada kategori rendah, dapat disimpulkan bahwa siswa tidak dapat menguasai indikator pertama, kedua dan ketiga dalam penyelesaiannya siswa masih terlihat belum memahami apa yang tertulis dalam pertanyaan sehingga masih kesulitan dalam menyelesaikan soal dan terlalu tergesa dalam menyelesaikannya. Fakta tersebut sesuai dengan pernyataan (Nari \& Musfika, 2016) mengatakan bahwa peserta didik kesulitan dalam memahami simbol - simbol dalam matematika dan bangun ruang, sehingga peserta didik tidak mengenak antar ide - ide matematika dalam variabel.

Hasil analisis yang diperoleh pada indikator kemampuan menarik kesimpulan berdasarkan contoh - contoh dapat disimpulkan bahwa masih diperoleh hasil tes yang dikatakan rendah. Karena siswa kurang memahami bentuk bangun datar sehingga tidak dapat menguasai indikator tersebut dengan baik. Fakta tersebut sesuai dengan pernyataan (Nurhikmayati, 2017) bahwa masih banyak siswa yang menerapkan konsep tidak sesuai dengan apa yang ditanyakan. Berdasarkan hasil wawancara siswa mengatakan bahwa tidak memahami pertanyaan sehingga langsung jawab berdasarkan yang dipikirkan.

Hasil temuan dilapangan siswa tidak ingat dengan materi yang sudah pernah diajarkan sehingga menghambat penyelesaian pada soal. Siswa yang berkemampuan kategori tinggi mampu menjawab pertanyaan, sedangkan siswa yang kemampuan kategorinya sedang dan rendah masih banyak mengalami kesulitan.

Penelitian ini dapat dijadikan sebagai sumber untuk mengetahui kesulitan siswa dalam menyelesaikan soal kemampuan berpikir logis matematis, sehingga pendidik lebih memahami dan dapat meminimalisir kesulitan yang terjadi dalam diri siswa.

\section{SIMPULAN}

Hasil penelitian menunjukkan bahwa pada materi bangun ruang seluruh indikator kemampuan berpikir logis belum terpenuhi secara maksimal oleh seluruh siswa. Sehingga dapat disimpulkan kesulitan siswa dalam menyelesaikan soal dengan indikator kemampuan berpikir logis matematis yaitu kurangnya memahami dan menguasai konsep.

Secara keseluruhan siswa dengan kategori sedang dan rendah mayoritas sering melakukan kesalahan, salah satunya tidak memahami konsep materi yang mengakibatkan siswa kesulitan dalam menyelesaikan soal kemampuan berpikir logis matematis, sedangkan siswa dengan kategori tinggi tidak mengalami kesulitan.

\section{DAFTAR PUSTAKA}

Agustini, D., \& Pujiastuti, H. 2020. Analisis Kesulitan Siswa Berdasarkan Kemampuan Pemahaman Matematis Dalam Menyelesaikan Soal Cerita Pada Materi SPLDV. Media Pendidikan Matematika, 8(1): 18-27.

Alawiyah, H., Muldayanti, N. D., \& Setiadi, A. E. 2016. Analisis Kesulitan Belajar Siswa Dalam Memahami Materi Invertebrata Di Kelas X MAN 2 Pontianak. Jurnal Bioeducation, 3(2): 9-20.

Andini, H. 2017. Pendekatan Pendidikan Matematika Realistik Indonesia (Pmri) Untuk Meningkatkan Kemampuan Berpikir Logis Siswa SMP. Skripsi Fakultas Keguruan Dan Ilmu Pendidikan Universitas Singaperbangsa Karawang.

Arikunto, S. 2010. Prosedur Penelitian Suatu Pendekatan Praktik. Rineka Cipta.

Dwidarti, U., Mampouw, H. L., \& Setyadi, D. 2019. Analisis Kesulitan Siswa Dalam Menyelesaikan Soal Cerita Pada Materi Himpunan. Jurnal Cendekia: Jurnal Pendidikan Matematika,3(2), 315-322.

Nari, N., \& Musfika, A. P. 2016. Analisis Kesulitan Belajar Ditinjau Dari Kemampuan Koneksi Matematika Peserta Didik. Iain Batusangkar. 311-320.

Noviani, J., Hakim, H., \& Jarwandi, J. 2020. Analisis Kemampuan Berpikir Logis Pada Materi Peluang Di Kelas IX SMP Negeri 1 Takengon. Jurnal Ilmiah Pendidikan Matematika Al Qalasadi. 4(1), 14-23.

Nurhikmayati, I. 2017. Kesulitan Berpikir Abstrak Matematika Siswa Dalam Pembelajaran Problem Posing Berkelompok. Kalamatika Jurnal Pendidikan Matematika, 2(2): 159-176.

Octaria, D. 2017. Kemampuan Berpikir Logis Mahasiswa Pendidikan Matematika Universitas Pgri Palembang Pada Mata Kuliah Geometri Analitik. Jurnal Pendidikan Matematika Rafa, 3(2): 181194.

Pratiwi, R. S., Kustati, M., \& Susanto, A. 2019. Strategi Belajar Think Talk Write Dan Kemampuan Berpikir Logis Matematis. Math Educa Journal, 3(1): 21-31.

Rumantinigsih, D. K., Astuti, E. P., \& Purwoko, R. Y. 2020. Mengatasi Kesulitan Belajar Matematika Pada Siswa Tunanetra Melalui 
Anisa Kurnia Septiya Utami dan Haerudin

Anargya: Jurnal Pendidikan Matematika, Vol. 4 No.1, April 2021

https://dx.doi.org/10.24176/anargya.v4i1.5762

Pengembangan Media Pandikar Berkode Braille. Jurnal Pendidikan Matematika Dan Matematika. 6(2), 105-114.

Sudirman, Cahyono, E., \& Kadir. (2018). Analisis

Kemampuan Koneksi Matematis Siswa

Smp Pesisir Ditinjau Dari Perbedaan

Gender. Jurnal Pembelajaran Berfikir

Matematika, 3(2): 11-22.

Utomo, S. 2019. Analisis Kemampuan Berpikir Logis Matematis Peserta Didik Pada Materi Barisan Dan Deret Aritmetika Berdasarkan Kemampuan Awal Matematika. Jurnal Simki-Techsain, 1-10. 